\title{
Recipients of 2019 AJCC Most Influential Paper Award
}

\author{
AJCC Editorial Board
}

How to cite this paper: AJCC Editorial Board (2019) Recipients of 2019 AJCC Most Influential Paper Award. American Journal of Climate Change, 8, 439-440. https://doi.org/10.4236/ajcc.2019.83023

Received: August 28, 2019

Accepted: September 22, 2019

Published: September 25, 2019

Copyright $\odot 2019$ by author(s) and ScientificResearch Publishing Inc. This work is licensed under the CreativeCommons Attribution International License (CC BY 4.0).

http://creativecommons.org/licenses/by/4.0/

\begin{abstract}
The AJCC Most Influential Paper Award recognizes papers that had significant impacts in the scientific community (e.g. cited by Nature, Science) or had more than 10 citations based on the Web of knowledge.
\end{abstract}

\section{Keywords}

AJCC Most Influential Paper Award

Each year the editorial board of American Journal of Climate Change (AJCC) reviews the papers published by AJCC to select the papers they consider to have had the most influence on the research of climate change and related fields since their original publication. The AJCC Most Influential Paper Award recognizes papers that had significant impacts in the scientific community (e.g. cited by Nature, Science) or had more than 10 citations based on the Web of knowledge. This award consists of a certificate listing the paper, the author's name and the author's affiliation and carries a financial prize of $\$ 600$ to cover the article processing charge of their future paper published by AJCC.

\section{Recipients of 2019 AJCC Most Influential Paper Award Are}

1) The following AJCC article was cited by Nature Climate Change

Belova, A., Mills, D., Hall, R., Juliana, A., Crimmins, A., Barker, C. and Jones, R. (2017) "Impacts of Increasing Temperature on the Future Incidence of West Nile Neuroinvasive Disease in the United States", American Journal of Climate Change, Vol. 6 No. 1, 2017, pp. 166-216. doi: 10.4236/ajcc.2017.61010.

2) The following articles had more than 10 citations based on the Web of knowledge

O. Penalba and J. Rivera, "Future Changes in Drought Characteristics over Southern South America Projected by a CMIP5 Multi-Model Ensemble", American Journal of Climate Change, Vol. 2 No. 3, 2013, pp. 173-182.

doi: $\underline{10.4236 / \text { ajcc.2013.23017. }}$. 
F. Strauss, E. Moltchanova and E. Schmid, "Spatially Explicit Modeling of Long-Term Drought Impacts on Crop Production in Austria", American Journal of Climate Change, Vol. 2 No. 3A, 2013, pp. 1-11.

doi: 10.4236/ajcc.2013.23A001.

Zittis, G., Hadjinicolaou, P. and Lelieveld, J. "Comparison of WRF Model Physics Parameterizations over the MENA-CORDEX Domain”, American Journal of Climate Change, Vol. 3 No. 5, 2014, pp. 490-511.

doi: 10.4236/ajcc.2014.35042. 